\title{
Cattle Stomach Contents Concentrate as Supplemental Lysine and Methionine Source for Single Combed White Leghorn Layers on Plant Protein-Based Diets
}

\author{
Dr. Angelito L. Lacadin ${ }^{1}$, Joel John P. Humag² \\ Nueva Vizcaya State University, Bayombong, Nueva Vizcaya, Philippines
}

\begin{abstract}
Eighty SCWL layers were randomly assigned to four dietary treatment groups of different lysine and methionine sources with the following objectives: (1) to determine and evaluate the effects of plant protein-based diets with CSCC as supplemental lysine and methionine source on egg production and egg quality of SCWL layers and (2) to determine and assess the economy of feeding plant protein-based diets with CSCC against the other dietary treatments.No significant variations were noted on cumulative hen-day egg production, but monthly hen-day egg production differed significantly among treatments especially during the third month of the study.Feed consumption, number of standard-sized egg,feed conversion ratio, egg mass, egg weight and shell thickness did not differ significantly varied among the scores, albumen height and Haugh unit values significantly varied among the different treatments.Mean percentages of jumbo, extra-large,large and medium sized eggs in each dietary treatment group were statistically similar in all treatment groups.Least feed cost pre egg of was incurred in SCWL layers fed with CSCC s lysine and methionine source in the diet translating to higher returns above feed cost.
\end{abstract}

Keywords: Supplemental lysine, supplemental methionine, plant protein-based diets, dietary treatments

\section{Introduction}

The current use of synthetic analogues of essential amino acids in formulated diets has revolutionized poultry feeding and nutrition. This is especially true with cheap plant protein-based diets that lack one or more of the essential amino acids required for proper growth and productivity of poultry. Fortification of plant protein-based dietary formulations with these synthetic analogues resulted in increased performance poultry use of these amino acid sources, however, has resulted in more expensive diets. This encourages poultry producers to search for cheaper sources of essential amino acids particularly lysine and methionine.

Attempts were made to formulate cheaper poultry diets with cattle stomach contents concentrate (CSCC) as lysine and methionine without impairing birds' performance. Several studies used plant protein-based diets with CSCC as lysine and methionine source for broilers and laying quails, respectively and found that feed cost was significantly reduced with a corresponding increase in returns above feed cost (RAFC). Increase in RAFC was attributed to improved bird performance in feed intake, weight gain, egg production ,feed efficiency and protein utilization. Similarly, egg type chicks and growing quails fed with plant protein diets with CSCC as lysine and methionine source have significantly reduced feed costs without any impairment in bird performance.

These previous studies prompted the conduct of similar feeding trials on Single Combed White Leghorn (SCWL) layers using plant protein-based diets with CSCC as lysine and methionine source with the following objectives: (1) to determine and evaluate the effects of plant protein-based diets with CSCC as supplemental lysine and methionine source on egg production and egg quality of SCWL layers.
(2) lysine and egg methionine analogues, animal protein as lysine and methionine source and a commercial layer mash diet on egg production and egg quality of SCWL layers and; (3) determine and assess the economy of feeding plant protein-based diets with CSCC against the other dietary treatments.

\section{Methodology}

\subsection{Experimental Design and Treatment}

Eighty SCWL layers were randomly distributed to four dietary treatment groups. Each treatment was replicated five times with four layers per replication. The dietary treatments were designated as follows;

Diet I(D1)- commercial layers mash diet (Control)

Diet II(D2)- conventional 17\% CP layer diet with animal protein as lysine and methionine source

Diet III (D3)- plant protein-based 17\% CP layer diet with synthetic lysine(L-lysine) and Methionine (DL-methionine) analogues

Diet IV (D4)- plant protein-based 17\% CP layer with CSCC as supplemental lysine and methionine source

\subsection{Feed Preparation}

Three layer diets were formulated. Diets 2,3 and 4 were isonitrogenous with $17 \% \mathrm{CP}$, and isocaloric with $2700 \mathrm{kcal}$ ME. Diet 1 is commercially formulated.

The basal feed ingredients were ground yellow corn, rice bran, fish meal, soy bean, copra meal, salt, vitamin-mineral premix, oyster shell, limestone and tricalcium phosphate. Diet 1 was a commercial layer diet, while Diet 2 was formulated with fish meal as the major protein and amino acids source. Diet 3 and 4 were plant protein-based with 


\section{International Journal of Science and Research (IJSR) \\ ISSN (Online): 2319-7064 \\ Index Copernicus Value (2013): 6.14 | Impact Factor (2015): 6.391}

soybean meal as the major protein source. Lysine and methionine deficiencies in these two diets were met with the addition of L-lysine and DL-methionine, and CSCC, respectively. Mixing was done at SADECOR Feed Mill, Solano, Nueva Vizcaya.
The ingredient composition and calculated analysis of the experimental diets are presented in Tables 1 and 2.

Table 1: Ingredient composition of the experimental diets

\begin{tabular}{|c|c|c|c|c|}
\hline Feed Ingredients & $\begin{array}{c}\text { DIET I } \\
\text { (Commercial Layer } \\
\text { Mash-Control) }\end{array}$ & $\begin{array}{c}\text { DIET II } \\
\text { (Conventional Diet } \\
\text { with Animal Protein) }\end{array}$ & $\begin{array}{c}\text { DIET III } \\
\text { (Plant Protein Based } \\
\text { with Synthetic Lysine } \\
\text { and Methionine) }\end{array}$ & $\begin{array}{c}\text { DIET IV } \\
\text { (Plant Protein Based } \\
\text { with CSSC) }\end{array}$ \\
\hline Corn, yellow & & 60.00 & 58.32 & 51.03 \\
\hline Rice Bran, D1 & & 3.86 & 3.70 & 1.83 \\
\hline Soybean meal & & 22.28 & 26.85 & 26.73 \\
\hline Fish meal, $60 \%$ & & 3.00 & 0.00 & 0.00 \\
\hline $\mathrm{CSCC}$ & & 0.00 & 0.00 & 10.00 \\
\hline Limestone & & 2.89 & 5.34 & 4.62 \\
\hline Salt & & 0.50 & 0.50 & 0.50 \\
\hline Vitamin-mineral premix & & 0.94 & 1.00 & 0.50 \\
\hline L-lysine & & 0.00 & 0.01 & 0.00 \\
\hline DL-methionine & & 0.06 & 0.09 & 0.00 \\
\hline Tricalcium phosphate & 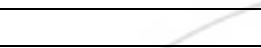 & 1.57 & 1.94 & 1.98 \\
\hline Zeolite & 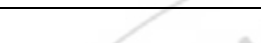 & 0.04 & 0.04 & 0.02 \\
\hline Antioxidant & $\bar{C}$ & 0.01 & 0.01 & 0.01 \\
\hline Total & 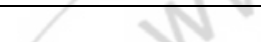 & 100.00 & 100.00 & 100.00 \\
\hline
\end{tabular}

Table 2: Calculated analysis of the experimental diets

\begin{tabular}{|c|c|c|c|c|}
\hline 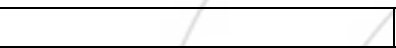 & DIET I & DIET II & DIET III & DIET IV \\
\hline Crude Protein, $\%$ & \multirow{7}{*}{$\begin{array}{c}\text { Guaranteed } \\
\text { analysis of } \\
\text { commercial feed }\end{array}$} & 17.00 & 17.00 & 17.00 \\
\hline Crude Fiber, $\%$ & & 3.43 & 3.49 & 5.93 \\
\hline Calcium, $\%$ & & 3.51 & 3.50 & 3.50 \\
\hline Total Phosphorus, $\%$ & & 0.61 & 0.61 & 0.60 \\
\hline Metabolizable Energy, kcal $/ \mathrm{kg}$ & & 2760.36 & 2733.16 & 2712.49 \\
\hline Lysine, \% & & 0.87 & 0.96 & 0.88 \\
\hline Methionine, $\%$ & & 0.33 & 0.32 & 0.32 \\
\hline
\end{tabular}

\subsection{Data Collection}

Data on egg production, egg weight, feed consumption, egg quality were collected. Feed conservation ratio, egg mass, cost of feed per egg produced and return above feed cost were calculated.

Health of the birds was closely monitored. Any deviation from normal health and general well-being were noted. Similarly, the physical response of the birds to the dietary treatments was also noted.

\section{Results and Discussion}

\subsection{Productive Performance of SCWL Layers Fed Plant Protein-Based Diets with CSCC as Supplemental Lysine and Methionine Source.}

Table 3 presents the productive performance of SCWL layers fed plant protein-based diets with CSCC as supplemental lysine and methionine source.

Table 3: Productive performance of single combed white leghorn (SCWL) layers fed plant protein-based diets with cattle

\begin{tabular}{|c|c|c|c|c|c|c|}
\hline Treatment & $\begin{array}{c}\text { Hen-day Egg } \\
\text { Production } \\
(\%)\end{array}$ & $\begin{array}{c}\text { Feed } \\
\text { Consumption } \\
(\mathrm{kg})\end{array}$ & $\begin{array}{c}\text { Adjusted no. of } \\
\text { Standard-sized } \\
\text { Egg }\end{array}$ & $\begin{array}{c}\text { Feed } \\
\text { Conversion } \\
\text { Ratio } \\
\end{array}$ & $\begin{array}{c}\text { Egg Mass } \\
(\mathrm{g})\end{array}$ & $\begin{array}{c}\text { Egg Weight } \\
\text { (g) }\end{array}$ \\
\hline $\operatorname{Diet} I\left(D_{1}\right)$ & 77.78 & 11.06 & 83 & 134.21 & 4708.58 & 67.24 \\
\hline Diet II $\left(\mathrm{D}_{2}\right)$ & 72.61 & 10.93 & 78 & 140.90 & 4425.07 & 66.32 \\
\hline Diet III $\left(\mathrm{D}_{3}\right)$ & 76.94 & 10.92 & 82 & 133.18 & 4653.71 & 67.28 \\
\hline Diet IV $\left(\mathrm{D}_{4}\right)$ & 80.11 & 11.04 & 85 & 129.97 & 4817.54 & 66.83 \\
\hline $\begin{array}{l}\text { F-test } \\
\mathrm{cv}(\%)\end{array}$ & $\begin{array}{c}n s \\
7.27\end{array}$ & $\begin{array}{c}* \\
0.80\end{array}$ & $\begin{array}{c}n s \\
7.39\end{array}$ & $\begin{array}{c}n s \\
7.84\end{array}$ & $\begin{array}{c}n s \\
7.39\end{array}$ & $\begin{array}{c}n s \\
2.77\end{array}$ \\
\hline
\end{tabular}

Hen-day egg production. Percentage hen-day egg production of experimental layers did not vary significantly. It was noted however, that layers fed with $\operatorname{CSCC}\left(\mathrm{D}_{4}\right)$ as supplemental lysine and methionine source have an average hen-day egg source have an average hen-day egg production of $80-11 \%$ that was slightly higher than the egg production of birds in other treatment groups (Table 3). This finding was consistent with what was obtained in laying Japanese Seattle quail where egg production of CSCC-fed birds did 


\section{International Journal of Science and Research (IJSR) \\ ISSN (Online): 2319-7064}

Index Copernicus Value (2013): 6.14 | Impact Factor (2015): 6.391

not differ significantly from those in the control treatment (Jallorina, 2000).

Monthly egg production showed that despite the absence of significant differences among treatment means, CSCC-fed birds consistently laid more eggs than those in other treatments until the second month of the study (Table 3). Significantly higher hen-day egg production was noted among birds in the commercial $\left(\mathrm{D}_{1}\right)$ and $\operatorname{CSCC}\left(\mathrm{D}_{4}\right)$ diets compared to those in the animal protein $\left(\mathrm{D}_{2}\right)$ and synthetic amino acid analogues $\left(\mathrm{D}_{3}\right)$ as sources of supplemental lysine and methionine.

Feed consumption. Average cumulative feed consumption of the experimental layers varied significantly among different treatment groups. Layers fed with commercial layer mash consumed significantly greater amount of feeds compared to birds fed with animal protein and synthetic amino acid analogues as lysine and methionine sources. However, this did not vary from feed consumption of CSCC-fed layers.

Number of standard-sized egg. Statistically, no significant variations were observed on number of standard-sized eggs from layers in the different treatment groups . Number of standard sized eggs ranged from 78 to 85 eggs per layer, with highest absolute number observed among CSCC-fed layers.

Birds fed with commercial layer mash, synthetic amino acids analogues and animal protein as lysine and methionine sources followed this with 83, 82 and 78 eggs per layer, respectively.

Feed conversion ratio. Feed conversion ratio was taken as the amount of feed consumed per standard-sized egg. This method was used to avoid bias due to variation in egg weight. Feed conversion ratio was statistically similar in all treatment groups. The lowest absolute FCR value of 129.97 however was noted among CSCC-fed layers suggesting that CSCC has at least improved feed efficiency among layers in this particularly dietary treatment group.

Egg mass. Egg mass ranged from 4425.07 to 4817.54 grams with no significant variations observed among the different treatment groups. It is worthwhile to note, however, that CSCC-fed layers produced eggs with heavier mass of $4817.54 \mathrm{~g}$ than birds in other treatment groups (Table 3 ).

Egg weight. Average egg weight from the experimental layers did not vary significantly. Egg weight ranged from 66.32 to $67.83 \mathrm{~g}$ with an average of $66.92 \mathrm{~g}$.

\subsection{Egg quality.}

Egg quality was measured in terms of yolk color, egg shell thickness, albumen height, and Hough Unit values (Table 4).
Table 4: Quality of eggs from SCWL layers fed plant protein-based diets with cattle stomach contents concentrate

(CSCC) as supplemental lysine and methionine source.

\begin{tabular}{|c|c|c|c|c|}
\hline Treatment & $\begin{array}{l}\text { Yolk } \\
\text { Color } \\
\text { Scores }^{\mathrm{a}} \\
\end{array}$ & $\begin{array}{c}\text { Egg Shell } \\
\text { Thickness } \\
\text { mm }\end{array}$ & $\begin{array}{c}\text { Albumen } \\
\text { Height } \\
\text { mm }^{b}\end{array}$ & $\begin{array}{c}\text { Haugh } \\
\text { Unit } \\
\text { Value }^{\mathrm{c}}\end{array}$ \\
\hline Diet I $\left(D_{1}\right)$ & $7.25^{\mathrm{b}}$ & 0.41 & $5.79^{b}$ & $71.17^{b}$ \\
\hline Diet II $\left(\mathrm{D}_{2}\right)$ & $9.50^{\mathrm{a}}$ & 0.38 & $6.25^{b}$ & $76.34^{\mathrm{ab}}$ \\
\hline Diet III $\left(\mathrm{D}_{3}\right)$ & $6.00^{\mathrm{c}}$ & 0.42 & $6.17^{b}$ & $76.54^{\mathrm{ab}}$ \\
\hline Diet IV $\left(D_{4}\right)$ & $9.00^{\mathrm{a}}$ & 0.44 & $7.00^{\mathrm{a}}$ & $80.97^{\mathrm{a}}$ \\
\hline F-test & $* *$ & $n s$ & $*$ & $*$ \\
\hline LSD-test $_{0.05}$ & 1.19 & - & 0.74 & 5.44 \\
\hline LSD-test $_{0.01}$ & 1.63 & - & 1.01 & 7.44 \\
\hline cv $(\%)$ & 10.12 & 6.96 & 7.93 & 4.82 \\
\hline
\end{tabular}

${ }^{a}$ Means in a column followed by similar superscripts are not significantly different at $1 \%$ level by LSD.

${ }^{b c}$ Means in a column followed by similar superscripts are not significantly different at $5 \%$ level by LSD.

Yolk color. Yolk color scores varied significantly among layers in the different treatment groups. Egg from layers fed with animal and plant protein-based diets have significantly higher yolk color scores compared to eggs from in the commercial and CSCC-supplemented diets. The high yolk color scores of egg from CSCC-fed layers could be attributed to the presence of xanthophyll in CSCC, which was purely derived from grasses ingested by cattle.

Shell thickness. Eggs from layers in all treatment groups have statistically similar shell thickness, suggesting identical effects of the diets on this parameter. This is expected since all dietary treatments contain similar amounts of calcium and phosphorus (Table 1), which are two major components of the eggshell. Shell thickness ranged from 0.38 to 0.44 $\mathrm{mm}$.

Albumen height. Albumen height was significantly higher in eggs produced from CSCC-fed layers compared to eggs from layers in other dietary treatments. This finding suggests a high availability of lysine and methionine from CSCC needed for albumen synthesis.

Haugh Unit. Haugh Unit as a measure of egg quality was significantly higher in eggs of fed layers compared to the control (commercial layer mash) diet-fed birds. No significant variations, however, were noted when Haugh Unit values of eggs from CSCC-fed layers were compared to those from the animal protein and synthetic lysine and methionine diets.

\subsection{Egg classification.}

Eggs from the experimental layers were classified based on weight and transformed to size equivalents. Mean percentages of the different eggs sizes from the experimental layers are shown in the Table 5.

Mean percentages of jumbo, extra-large, large and medium sized eggs in each dietary treatment group were statistically similar suggesting that the source of lysine and methionine did not significantly influence egg size. A closer examination however, shows that almost $50 \%$ of eggs laid by the experimental layers in all treatment groups were large sized. 


\section{International Journal of Science and Research (IJSR) \\ ISSN (Online): 2319-7064 \\ Index Copernicus Value (2013): 6.14 | Impact Factor (2015): 6.391}

Table 5: Mean percentages of jumbo, extra-large, large and medium sized eggs from SCWL layers fed plant protein-based diets with cattle stomach contents concentrate (CSCC) as supplemental lysine and methionine source.

\begin{tabular}{|l|c|c|c|c|c|}
\hline \multicolumn{1}{|c|}{ Treatment } & Jumbo & Extra-large & Large & Medium & Total \\
\hline Diet I $\left(\mathrm{D}_{1}\right)$ & 24.98 & 44.21 & 29.18 & 1.63 & 100.00 \\
\hline Diet II $\left(\mathrm{D}_{2}\right)$ & 24.91 & 46.72 & 26.75 & 1.62 & 100.00 \\
\hline Diet III $\left(\mathrm{D}_{3}\right)$ & 20.55 & 49.68 & 27.22 & 2.55 & 100.00 \\
\hline Diet IV $\left(\mathrm{D}_{4}\right)$ & 22.36 & 51.12 & 25.44 & 1.08 & 100.00 \\
\hline Mean & 23.20 & 47.20 & 27.15 & 1.72 & \\
F-test & $\mathrm{ns}$ & $\mathrm{ns}$ & $\mathrm{ns}$ & $\mathrm{ns}$ & \\
cv $(\%)$ & 17.33 & 10.59 & 18.47 & 31.51 & \\
\hline
\end{tabular}

3.4 Economy of CSCC as supplemental lysine and methionine source for SCWL layers.

The economy of CSCC as supplemental lysine and methionine source for SCWL layers is presented in Table 6.

Table 6: Economy of cattle stomach contents concentrates (CSCC) as supplemental lysine and methionine source for SCWL layers fed plant protein-based diets.

\begin{tabular}{|c|c|c|c|c|}
\hline \multirow[b]{2}{*}{ Item } & \multicolumn{4}{|c|}{ Treatment } \\
\hline & Diet I & Diet II & Diet III & Diet IV \\
\hline $\begin{array}{l}\text { Average number of eggs } \\
\text { produced }^{\mathrm{a}}\end{array}$ & 83 & 78 & 82 & 85 \\
\hline Price per egg, $\mathrm{P}^{\mathrm{b}}$ & 3.50 & 3.50 & 3.50 & 3.50 \\
\hline Average sales of eggs, $\mathbf{P}$ & 290.50 & 273.00 & 287.00 & 297.50 \\
\hline $\begin{array}{l}\text { Average feed } \\
\text { consumption, } \mathrm{kg}\end{array}$ & 11.06 & 10.93 & 10.92 & 11.04 \\
\hline $\begin{array}{c}\text { Average feed } \\
\text { consumption/egg, } g\end{array}$ & 134.21 & 140.90 & 133.18 & 129.97 \\
\hline $\begin{array}{l}\text { Cost of feed per egg } \\
\text { produced, } \mathrm{P}^{\mathrm{c}}\end{array}$ & 1.92 & 2.04 & 1.92 & 1.76 \\
\hline $\begin{array}{c}\text { Cost per } 100 \mathrm{~kg} \text { feed mix, } \\
\mathrm{P}\end{array}$ & 1430.00 & 1446.89 & 1440.25 & 1352.73 \\
\hline Cost per feed, $\mathbf{P}$ & 14.30 & 14.47 & 14.40 & 13.53 \\
\hline $\begin{array}{l}\text { Average cost of feed } \\
\text { consumed, } \mathrm{P}\end{array}$ & 158.16 & 158.16 & 157.25 & 149.37 \\
\hline Return above feed cost, $\mathrm{P}$ & 132.34 & 114.84 & 129.75 & 148.13 \\
\hline
\end{tabular}

${ }^{c}$ Based on adjusted egg size

Least feed cost of $\mathrm{P} 1.76$ per egg was incurred in SCWL layers fed with CSCC as lysine and methionine source in the diet. Layers fed with synthetic lysine and methionine analogues incurred the highest feed cost of $\mathrm{P} 148.13$ was realized from CSCC-fed layers. Return above feed cost derived from bird in other dietary treatment groups ranged from $\mathrm{P} 114.84$ to $\mathrm{P} 132.34$.

These findings point out that feeding SCWL layers with CSCC supplement plant protein-based diets could reduce feed costs and result in more profits compared to birds in other dietary treatments.

\subsection{Other observations}

Generally, the experimental birds are healthy with no deviation from normal during the entire duration of the experiment. However, during days when temperature increased, there was a slight drop in egg production and incidence of soft shelled eggs especially during the $7^{\text {th }}$ week of the study. This could be attributed to increase in water intake during the said week.
There was no change in skin, shank and beak pigmentation in all experimental layers. However, molting was observed on layers fed with the control and animal protein-based diets during the $5^{\text {th }}$ week, and layers fed with the plant proteinand CSCC- based diets during the $8^{\text {th }}$ week of the experiments.

\section{Conclusion and Recommendation}

\subsection{Conclusion}

Use of CSCC as supplemental lysine and methionine source could enhance the productive performance of SCWL layers, not only in number of eggs but also in terms of egg quality. Moreover, feeding layers with CSCC reduces feed costs and increases profits from egg production.

\subsection{Recommendation}

Findings of the study recommended the use of CSCC as an efficient supplemental lysine and methionine source for SCWL layers to boost egg production, improve egg quality, reduce costs and increase profits. Consistency of findings from previous studies further supports this recommendation.

\section{References}

[1] JALLORINA, V.A. 2000 Cattle stomach contents concentrate as supplemental lysine and methionine sources for laying Japanese Seattle Quails (Coturnixjaponicum) plant protein-based diets. NVSIT Research Journal. 9 (1,2):11-16.

[2] QUITOS, D.N. 1997. Cattle stomach contents concentrate as lysine and methionine source for broilers on low-protein diets. NVSIT Research Journal. 7 $(1,2): 43-49$. 